\title{
FENOMENA KORUPSI PEJABAT PUBLIK DI JAWA BARAT DAN CARA MENGATASINYA
}

\author{
Nur Atnan \\ email: nuratnan@telkomuniversity.ac.id
}

\begin{abstract}
The negative effect of the decentralization policy implemented since 2001 is that corruption too become decentralized, especially in West Java. This article discusses: (1) patterns of corruption; (2)probable causes of corruption by government officials; and (3) proposed solution. To do just that, the author chose a socio legal research approach. Empirical data was collected through in depth interview. The main findings are: (1) Corruption in West Java mostly took the form of state budget misappropriation; (2) the major source of corruption is abuse of power, money politics and the tendency to misuse loopholes in rules and regulations. Law enforcement should therefore focus on betterment of regulation, organizational structure and legal culture of the officers.
\end{abstract}

Keywords: corruption, corruption pattern, law enforcement institutions, and government officials.

\begin{abstract}
Abstrak
Dampak negatif kebijakan Otonomi Daerah yang diberlakukan sejak 2001 adalah desentralisasi korupsi. Korupsi di daerah, khususnya Jawa Barat tidak terlepas dari persoalan sistem baik sistem pemerintahan/politik maupun sistem hukum. Tulisan ini akan menjelaskan tiga hal, yaitu (1) pola korupsi; (2) faktor penyebab; dan (3) solusi yang dapat ditawarkan. Tulisan ini menggunakan pendekatan socio legal research. Data empirik dikumpulkan melalui in-depth interview. Temuan utama penelitian ini ialah: (1) Mayoritas korupsi di Jawa Barat bersumber dari penyalahgunaan anggaran Negara; (2) Penyebabnya adalah penyalahgunaan wewenang oleh pejabat daerah, politik uang dan pemanfaatan celah dalam regulasi. Penegak hukum, karena itu, harus memfokuskan diri pada pembenahan sektor regulasi, struktur kelembagaan, dan budaya hukum aparat.
\end{abstract}

Kata Kunci:

Korupsi, Pola Korupsi, Lembaga Penegak Hukum, dan Pejabat Publik

\section{Pendahuluan}

Dampak negatif dari kebijakan Otonomi Daerah yang diberlakukan sejak tahun 2001 adalah desentralisasi korupsi. Kejahatan luar biasa ini tidak hanya marak di pusat, tetapi juga menjalar hingga ke daerah. Modus korupsinya dilakukan melalui mark up belanja, menjadi broker proyek hingga manipulasi pejalanan dinas. Tindakan ini dapat dilakukan oleh pejabat eksekutif, legislatif, atau pihak swasta. Bahkan dimungkinkan terjadinya kolaborasi antara tiga unsur tersebut, misalnya antara eksekutif dan legislatif, antara pihak swasta dengan eksekutif dan antara pihak swasta dengan legislatif melalui modus broker proyek. 
Objek korupsi di daerah adalah dana APBD. Akhir-akhir ini, korupsi dana APBD di daerah banyak menjerat pejabat eksekutif. Sementara itu untuk pejabat legislatif masih sedikit yang terungkap. Hanya tahun 2009 saja penegak hukum banyak mengungkap kasus yang melibatkan legislatif di daerah (ICW, 2009, tren korupsi). Pasca 2009, korupsi banyak di lakukan oleh pejabat eksekutif. Fenomena ini sedikit berbeda dengan pengungkapan korupsi di pusat. Dalam perkembangan terkini, di pusat, kasus korupsi yang dibongkar kebanyakan melibatkan legislatif. Sehingga tidak heran jika hasil survey yang di rilis Soegeng Sarjadi Syndicate (SSS) pada tahun 2012 menempatkan lembaga DPR (47\%) sebagai lembaga terkorup.

Tren korupsi tahun 2010 menunjukkan bahwa dana APBD menjadi sektor utama yang dikorupsi. Hasil penelitian ICW menunjukkan bahwa semester I tahun 2010, korupsi di sektor ini menempati urutan pertama dengan 38 kasus. Pada semester II di tahun yang sama, terjadi peningkatan kasus yakni 44 kasus. Pelakunya di dominasi oleh pejabat eksekutif. Terdapat 21 kasus yang melibatkan kepala daerah, 70 kasus yang melibatkan kepala dinas, dan sisanya 86 kasus melibatkan perangkat lain seperti sekda, asisten, camat, dan perangkat lurah/desa. Hanya pada tahun 2009 tren korupsi banyak mendera anggota DPRD.

Berdasarkan hasil audit BPK pada tahun 2011 terhadap laporan keuangan 33 provinsi di Indonesia, telah terjadi kerugian negara akibat prilaku koruptif pejabatnya sebesar Rp. 4,1 Triliun. Temuan ini seolah ingin membenarkan hasil penelitian ICW sebelumnya bahwa keuangan daerah menjadi sektor utama yang di korup. Dari laporan audit tersebut, menempatkan DKI Jakarta sebagai provinsi terkorup yakni ada sekitar Rp. 721,5 Miliyar. Daerah terkorup selanjutnya kebanyakan ditempati oleh daerah-daerah yang berada di luar pulau jawa. Untuk pulau jawa sendiri posisi kedua ditempati oleh Jawa Barat. Sepanjang tahun 2011, diduga ada sekitar Rp. 32,4 Miliyar potensi keuangan daerah yang dikorup.

Tumbuh suburnya korupsi di daerah termaksud di Jawa Barat tidak terlepas dari persoalan sistem baik sistem pemerintahan/politik maupun sistem hukum. Persoalan sistem pemerintahan terkait dengan peran eksekutif dan 
legislatif daerah khususnya dalam penganggaran yang tidak profesional, banyak permainan dan cenderung tertutup. Dari pola rekrutmen anggota legislatif pun menjadi persoalan karena adanya kewajiban-kewajiban tidak tertulis yang cukup memberatkan sehingga mendorong mereka untuk mencari tambahan-tambahan lain ketika suda duduk di lembaga legislatif. Harapan pada lembaga penegak hukum pun seolah sulit karena mereka menghadapi kendala tersendiri dalam mengungkap kasus korupsi yang khusus melibatkan pejabat publik.

Tulisan ini akan membahas beberapa hal, yaitu (1) Bagaimana pola-pola korupsi yang melibatkan pejabat publik di Jawa Barat; (2) Faktor-faktor apa yang menyebabkan korupsi pejabat publik di Jawa Barat; dan (3) Apa solusinya agar penyelesaian kasus korupsi pejabat publik oleh lembaga penegak hukum bisa lebih efektif di Jawa Barat.

Tulisan ini didasarkan pada hasil penelitian yang menggunakan metode kualitatif dengan pendekatan socio legal research dengan melibatkan narasumber dari Polda, Kejati, Pengadilan Tipikor, Tim Anggaran Pemda, Banggar DPRD, Pengurus Parpol, Akademisi, NGO, dan Media Massa di Wilayah Jawa Barat. Teknik pengumpulan data dilakukan dengan cara studi dokumen dan In Depth Interview. Analisis data dilakukan dengan cara data reduction, data display dan conclusion drawing/verification.

Terdapat tiga konsep yang digunakan untuk menganalisis permasalahan dalam tulisan ini. Konsep-konsep tersebut meliputi Korupsi, Lembaga Penegak Hukum, Sistem Hukum dan Penegakkan Hukum.

Dalam perspektif hukum definisi korupsi dapat dilihat dalam Encyclopedia of Crime and Justice, pengertian corruption menunjuk pada kata bribery yang mengandung arti :

"the act or practice of benefiting a person in order to betray a trust or to perform a duty meant to be performed freely, bribery occurs in relation to a public official and derivatively, in private transaction. ${ }^{1}$ Sedangkan dalam Black's Law Dictionary kata Corruption diartikan sebagai : "an act done with an inten to give some advantage inconsistence with

\footnotetext{
${ }^{1}$ Sanford H. Kadish, Encyclopedia of Crime and Justice, The Free Press, 1983, hlm. 278 dan 119.
} 
official duty and the right of others. The of an offical or fiduciary person who unlawfully and wrongfully uses his station or character to procure some benefit for himself or for another person, contrary to duty and the rights of others. Dalam Blak's Law Dictionary selanjutnya juga menunjuk pada pengertian bribery atau extortion.

Korupsi dalam konteks politik dan hukum, pada umumnya dikaitkan dengan pejabat publik, keuangan negara dan untuk memperoleh keuntungan pribadi atau orang lain. Menurut Ulsaner secara konseptual korupsi amat sulit untuk dijelaskan. Setiap definisi selalu bermasalah, karena tidak cukup mewakili kerumitan arti kata itu. Dalam penelitian digunakan pengertian korupsi dalam arti luas, yaitu penyalahgunaan kekuasaan publik untuk kepentingan pribadi. Kekuasan publik disini diartikan sebagai kekuasaan yang diberikan oleh publik dan publik bisa berarti masyarakat ataupun organisasi-organisasi yang ada di dalamnya. ${ }^{2}$

Banyak teori yang menjelaskan sebab-sebab terjadinya korupsi. Menurut G. Jack Bologna korupsi disebabkan oleh 4 hal (dikenal dengan teori GONE), yaitu :

$\mathrm{G}=$ Greek (tamak)

$\mathrm{O}=$ Opportunity (kesempatan)

$\mathrm{N}=$ Need (dorongan manusia untuk memenuhi kebutuhannya)

$\mathrm{E}=$ Exposure (tindakan bila koruptor ditangkap). ${ }^{3}$

Pada awalnya di Indonesia terdapat 3 (tiga) lembaga negara yang memiliki kewenangan berkaitan dengan tindak pidana korupsi diantaranya Kepolisian, Kejaksaan dan Pengadilan Tindak Pidana Korupsi. Pasca reformasi kemudian dimulai suatu agenda pemberantasan korupsi yang menghasilkan suatu lembaga baru yakni Komisi Pemberantasan Korupsi (KPK) dan adanya satu cabang baru dalam pengadilan umum, yakni pengadilan tindak pidana korupsi.

Ada beberapa tujuan hukum yang sering kita dengar di kehidupan seharihari, diantaranya mewujudkan ketertiban dalam masyarakat, memberikan rasa

\footnotetext{
2 Reza A.A. Wattimena, Filsafat Anti Korupsi, Kanisius., hlm. 10

${ }^{3}$ Hadi Setia Tunggal, Undang-undang Nomor 7 Tahun 2006 tentang Pengesahan Konvensi PBB Anti Korupsi, 2003, Harvarindo, 2006, hlm iii.
} 
keadilan dan juga kepastian dalam hukum itu sendiri. Dalam upaya mencapai tujuan hukum tersebut, kaidah-kaidah hukum yang ada haruslah tersusun dalam sebuah sistem. Sebab Jika tidak maka tidak mustahil atau akan mudah terjadi pertentangan antar kaidah hukum yang akan menyebabkan keberadaan hukum menjadi problematis dan tidak fungsional. ${ }^{4}$

Lawrence M. Friedman seorang sosiolog hukum, dalam teori sistem hukum yang ia kemukakan, sebagai suatu tatanan sistem, hukum terdiri atas tiga subsistem, diantaranya sebagai berikut $^{5}$. Pertama adalah legal substance (substansi hukum), yakni keseluruhan aturan-aturan, kaidah-kaidah atau asasasas hukum yang biasa disebut sebagai tata-hukum. ${ }^{6}$ Dalam hal korupsi, terdapat beberapa aturan hukum yang berkaitan seperti Undang-Undang No. 31 Tahun 1999 jo. Undang-Undang No. 20 Tahun 2001 tentang pemberantasan tindak pidana korupsi, Undang-Undang no. 30 tahun 2002 tentang Komisi Pemberantasan Korupsi dan sebagainya.

Kedua adalah legal structure (struktur hukum), yakni unsur penggerak atau pelaksana dari hukum itu sendiri, didalamnya terdiri dari organisasi-organisasi, lembaga-lembaga termasuk pejabat-pejabatnya. Dalam konteks korupsi yakni lembaga-lembaga seperti pemerintah (eksekutif), legislatif dan yudikatif dengan aparatnya para birokrat, Komisi Pemberantasan Korupsi, Kepolisian, Kejaksaan dan pengadilan termasuk pula para advokat. Ketiga adalah legal culture (budaya hukum), yakni berkaitan dengan pikiran dan kekuatan sosial mengenai bagaimana hukum itu digunakan atau disalahgunakan baik oleh para struktur hukum

\footnotetext{
${ }^{4}$ B. Arief Sidharta, 2011, asas hukum, kaidah hukum, sistem hukum dan penemuan hukum, dalam "Negara Hukum yang Berkeadilan" Kumpulan Tulisan dalam Rangka Purnabakti Prof. Dr. Bagir Manan, S.H., M.CL., PSKN FH UNPAD, Bandung, hlm. 8

5 Baca lebih lanjut dalam Lawrenca M. Friedman, 1975, The legal system: a social science perspective, Russel Sage Foundation, New York, hlm. 14

${ }^{6}$ B. Arief Sidharta, 2011, asas hukum, kaidah hukum, sistem hukum dan penemuan hukum, dalam "Negara Hukum yang Berkeadilan" Kumpulan Tulisan dalam Rangka Purnabakti Prof. Dr. Bagir Manan, S.H., M.CL., PSKN FH UNPAD, Bandung, hlm. 8
} 
maupun masyarakat. Untuk mewujudkan suatu sistem hukum yang baik, maka ketiga komponen tersebut haruslah dikembangkan secara simultan dan integral. ${ }^{7}$

Digunakannya konsep negara hukum di Indonesia yang termaktub dalam Pasal 1 ayat (3) Undang-Undang Dasar 1945 berkonsekuensi terhadap keharusan untuk menegakkan hukum. Bagir Manan menyatakan bahwa penegakan hukum merupakan suatu bentuk konkrit penerapan hukum dalam masyarakat yang akan mempengaruhi perasaan hukum, kepuasan hukum dan kebutuhan atau keadilan hukum masyarakat. ${ }^{8}$ sehingga jika suatu negara hukum memiliki kualitas yang buruk dalam penegakan hukum tentu akan menimbulkan gejolak-gejolak di masyarakat karena tidak tercapainya tujuan hukum seperti ketertiban dan keadilan.

Sehingga dapat disimpulkan dari perspektif yang sempit, upaya yang dilakukan oleh Kepolisian, Kejaksaan dan pengadilan dalam rangka memberantas tindak pidana korupsi termasuk kedalam upaya penegakan hukum. Namun perlu digarisbawahi bahwa upaya penegakkan hukum sebaiknya tidak hanya upaya untuk menegakkan peraturan formal yang tertulis saja, namun juga melibatkan nilai-nilai keadilan yang hidup di masyarakat.

\section{Pola-pola Korupsi yang Melibatkan Pejabat Publik di Jawa Barat}

Mengacu pada UU No. 31 Tahun 1999 jo. UU No. 20 Tahun 2001, pada dasarnya terdapat 30 bentuk/jenis tindak pidana korupsi. Dari 30 bentuk/jenis tersebut, terbagi dalam 7 kelompok besar, yaitu (1) perbuatan yang menimbulkan kerugian keuangan negara; (2) suap menyuap; (3) penggelapan dalam jabatan; (4) pemerasan; (5) perbuatan curang; (6) benturan kepentingan dalam pengadaa; dan (7) gratifikasi. Berikut jumlah kasus korupsi yang terjadi di Jawa Barat dan melibatkan pejabat publik berdasarkan kategorisasi kelompok perbuatan korupsi:

7 Patrialis Akbar, 2010, Peran Kementerian Hukum dan Hak Asasi Manusia dalam Menciptakan Supremasi Hukum, Jurnal Sekretariat Negara no. 15, hlm. 19

${ }^{8}$ Dikutip dari Rahayu prasetianingsih, negara hukum dan penegakan hukum dalam "Negara Hukum yang Berkeadilan" Kumpulan Tulisan dalam Rangka Purnabakti Prof. Dr. Bagir Manan, S.H., M.CL., PSKN FH UNPAD, Bandung, hlm. 553 
Grafik 1. Klasifikasi Kelompok Kasus Korupsi Pejabat Publik yang Terjadi di Jawa Barat Januari 2013 s.d. Agustus 2013

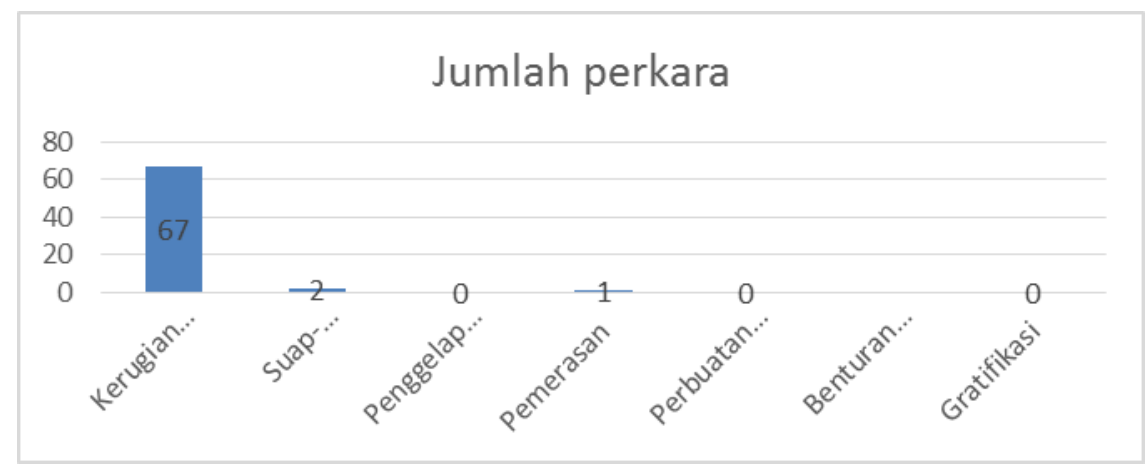

Sumber: Diolah oleh Penulis

Berdasarkan grafik diatas, terdapat tiga tipe perbuatan korupsi di Jawa Barat, yaitu (1) Perbuatan yang menimbulkan kerugian negara; (2) Suapmenyuap; dan (3) Pemerasan. Dari tiga tipe tersebut, yang jumlahnya sangat signifikan adalah perbuatan yang menimbulkan kerugian keuangan negara.

Jika diurai lebih spesifik, ada beberapa modus korupsi yang terjadi di Jawa Barat. Modus korupsi bisa berlainan tergantung pejabat publik yang terlibat korupsi. Menurut Andi Hamzah, modus korupsi adalah cara-cara pelaku melakukan perbuatan korupsi. ${ }^{9}$ Hampir semua pejabat pernah terlibat korupsi di Jawa barat, mulai dari gubernur, anggota DPRD provinsi, bupati/walikota, anggota DPRD kabupaten, birokrat hingga kepala desa.

\section{Modus Korupsi Level Gubernur/Bupati/Walikota}

Sedikitnya terdapat sembilan modus korupsi yang bisa dilakukan oleh gubernur dalam posisinya sebagai kepala daerah. Pertama, korupsi melalui APBD. Kedua, kemungkinan kolusi antara penguasa dan pengusaha terutama di bidang dunia usaha. Ketiga, pengadaan barang yang sering terjadi mark-up. Keempat, penerimaan pajak yang sering tidak masuk ke khas negara. Kelima, pendaftaran

9 Muhtar Haboddin dan Fatur Rahman, Gurita Korupsi Pemerintah Daerah, Yogyakarta: Kaukaba Dipantara (2013). 
pegawai pemerintah dengan pungutan yang tidak semestinya. Keenam, pengurusan izin apapun. Ketujuh, pemanfaatan bantuan dan program lembaga lain. Kedelapan, melakukan kegiatan fiktif atau meminta bagian dari bantuan yang diterima masyarakat. Kesembilan, menggelapkan bantuan yang diterima. ${ }^{10}$

Dari sembilan modus tersebut, modus korupsi yang pernah terjadi di Jawa Barat yang menimpa mantan Gubernur adalah mark-up dana proyek. Hal ini terjadi pada Danny Setiawan yang suda divonis 4 tahun penjara oleh Pengadilan Tipikor pada tahun 2009. Kasusnya berupa Korupsi pengadaan mobil pemadam kebakaran, ambulans, dan stoomwalls.

Sementara itu, modus korupsi yang pernah menimpa bupati/walikota adalah suap dan korupsi dana APBD. Modus suap pernah dilakukan oleh Mochtar Muhammad, mantan walikota Bekasi yang menyuap anggota DPRD senilai Rp. 1,6 miliar, suap piala Adipura Rp. 500 juta serta suap BPK senilai Rp. 400 juta. Sedangkan modus korupsi dana APBD pernah dilakukan oleh Eep Hidayat (mantan Bupati Subang) berupa korupsi biaya pemungutan Pajak Bumi dan Bangunan (PBB) senilai Rp. 14 miliar.

Korupsi dana APBD juga pernah dilakukan oleh Mochtar Muhammad (mantan walikota Bekasi) berupa penyalahgunaan uang makan minum senilai Rp. 639 juta. Sedangkan wakil walikota Bogor pernah diproses karena modus korupsi yang sama yakni korupsi dana APBD tahun 2004 untuk penunjang kegiatan anggota senilai 6,026 miliar. Dalam perkembangan peradilan, Achmad Ru'yat pada akhirnya divonis bebas oleh MA.

Modus lain yang pernah menimpa walikota dilingkup Jawa Barat adalah modus korupsi dana Bansos. Lebih teknis yang dilakukan berupa penyalahgunaan dana publik untuk kepentingan organisasi tertentu. Kasus ini menimpa mantan walikota Bandung, Dada Rosada. Dalam perkembangan peradilan, banyak organisasi fiktif yang menerima dana Bansos. Sejauh ini, kasus ini awalnya ditangani oleh kejaksaan namun diambil alih oleh KPK karena hakim tipikor yang

10 Id. 
menangani kasus ini justru terkena suap. Hingga laporan ini dibuat, Dada Rosada sudah menjadi tersangka dan proses hukumnya masih berjalan.

\section{Modus Korupsi di DPRD Provinsi dan Kabupaten/Kota}

Dari hasil study PUKAT UGM, modus korupsi di DPRD terjadi pada semua lini fungsi yang melekat padanya. Terdapat tiga fungsi atau kewenangan DPRD, yaitu fungsi legislatif, fungsi pengawasan dan fungsi anggaran. Disetiap level fungsi, terdapat beberapa modus korupsi.

Dari data yang ada, modus korupsi di level fungsi legislatif sejauh ini belum terjadi di Jawa Barat. Sedikitnya ada tiga modus dalam level ini, yaitu komersialisasi pasal, studi banding, dan pengesahan peraturan daerah. Dalam tiga tahun terakhir, belum ada kasus terkait dengan tiga modus ini.

Anggota DPRD baik provinsi maupun kabupaten/kota di Jawa Barat banyak yang terlibat dalam kasus korupsi dana bansos. Beberapa anggota DPRD yang terbelit korupsi dana Bansos meliputi beberapa anggota DPRD Kabupaten Garut, Kabupaten Bandung, Kabupaten Subang, dan Kabupaten Cianjur. Korupsi dana Bansos masuk dalam kategori modus permainan penggunaan dana-dana bantuan. Dalam studi PUKAT, modus tersebut dilakukan saat DPRD menjalankan fungsi pengawasan. Korupsi ini dilakukan dengan cara menggiring eksekutif agar memilih organisasi tertentu untuk mendapatkan dana Bansos. Ketiga dana turun, anggota DPRD mendapatkan fee.

Modus lain yang terjadi adalah saat pengadaan barang dan jasa. Hal ini terjadi pada anggota DPRD Kota Cirebon. Kasusnya berupa penyelewengan dana belanja barang dan jasa senilai Rp. 4,9 miliar dalam APBD Kota Cirebon 2004. Selain itu, terdapat modus berupa korupsi dana bencana alam. Kasus ini terjadi di Kabupaten Garut. Ada dua anggota DPRD yang terlibat, yaitu Rajab Prilyadi Syam dan Agus Ridwan. Dana bencana yang dikorup adalah dana bencana di tahun anggaran 2007. 


\section{Modus Korupsi di Birokrasi}

Birokrarasi dijalankan oleh birokrat yang merupakan aparat yang membantu kepala daerah dalam menjalankan roda pemerintahan. Terdapat sedikitnya lima modus korupsi di level ini, yaitu (1) suap; (2) manipulasi tender atau kontrak; (3) pembuatan surat perjalanan fiktif; (4) mark-up pengadaan barang; dan (5) melakukan pembukuan yang tidak benar. ${ }^{11}$

Dalam tiga tahun terakhir, sedikitnya terdapat tiga modus korupsi yang terjadi dalam birokrasi di Jawa Barat. Berdasarkan analisis data kasus korupsi yang ada, modus tersebut meliputi suap, mark-up, dan pembukuan yang tidak benar. Modus suap salah satunya terjadi pada kasus bansos yang melibatkan mantan walikota bandung Dada Rosada. Pemberi suap adalah staf/pegawai pemerintah kota bandung.

Modus mark-up terjadi pada beberapa kasus, misalnya pada proyek pengadaan Unit Pengelola Sampah (UPS) di kota Depok. Kasus ini melibatkan pegawai dinas pasar, koperasi dan UKM Kota Depok dan menimbulkan kerugian negera sebesar Rp. 170 juta. Selain itu, terdapat pula kasus proyek pengadaan peralatan multi media di Kota Bekasi. Kasus ini melibatkan kepala dinas sosial Kota Bekasi.

Modus terakhir adalah pembukuan yang tidak benar. Hal ini terjadi di beberapa daerah di Jawa Barat. Misalnya yang terjadi di Kabupaten Cianjur dalam kasus korupsi dana operasional makanan dan minum sebesar Rp 7,5 miliar. Pejabat yang terlibat adalah Kepala Dinas Tata Ruang dan Pemukiman dan Kepala Sub Bagian Rumah Tangga Kabupaten Cianjur. Hal yang sama juga terjadi di Kabupaten Ciamis yaitu kasus korupsi bantuan dari provinsi Jawa Barat kepada Komite Olahraga Nasional (KONI) Kabupaten Ciamis senilai Rp. 3 miliar.

${ }^{11}$ Id. 


\section{Korupsi Pejabat Publik dan Faktor-Faktor Penyebabnya di Jawa Barat}

Kondisi terkini terkait dengan isu korupsi adalah aktor yang terlibat makin bervariasi dan modus korupsinya makin canggih. Tidak hanya terjadi dalam konteks nasional, tetapi di daerah mengalami hal yang sama tidak terkecuali di Jawa Barat. Pelakunya bukan saja pejabat eksekutif dan legislatif, tetapi juga judikatif.

Provinsi Jawa Barat menjadi salah satu provinsi terbesar di Indonesia. Tidak hanya jumlah penduduknya yang besar, tetapi APBD nya pun terbilang besar. Pada tahun 2010, APBD Jawa Barat sebesar 9,56 Triliun. Di tahun selanjutnya, 2010 besaran APBD mengalami peningkatan 3,81\% sehingga menjadi 9,837 Triliun. Pada tahun 2012 APBD Jawa Barat melonjak naik hingga mencapai 14,626 Triliun. ${ }^{12}$

Grafik 2. Tren Kenaikan APBD Jawa Barat 2010, 2011, dan 2012 (dalam Triliun)

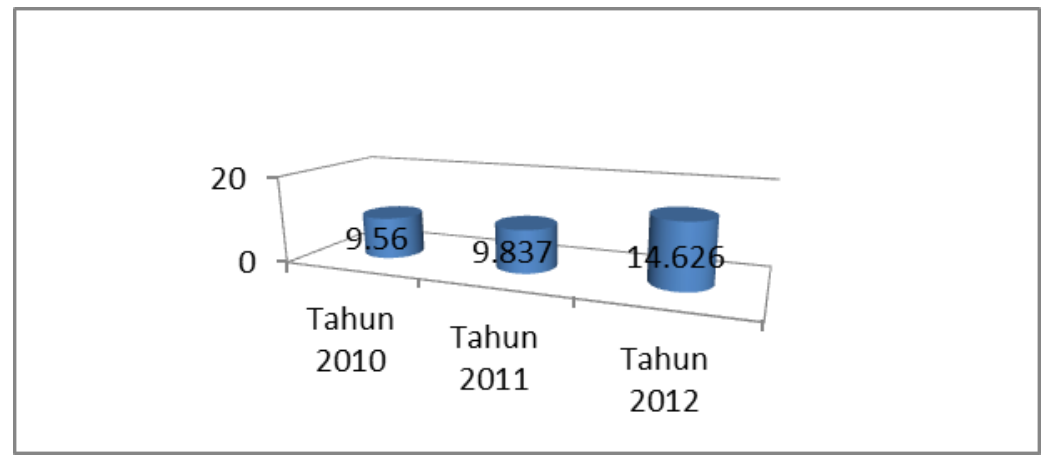

Sumber : Diolah oleh Penulis

Sudah menjadi rahasia umum bahwa APBD merupakan sumber utama yang menjadi sasaran para pejabat di daerah untuk di korupsi. Hal ini diperkuat oleh pantauan ICW pada tahun 2011, dimana sektor keuangan daerah menjadi sektor terawan untuk dikorup. Objeknya tidak lain adalah APBD. Makin besar dana APBD nya, maka besar peluang dana yang akan di korup. Terkait dengan korupsi di Jawa Barat, laporan masyarakat untuk masalah ini cukup besar. Data

12 bisnis.news.viva.co.id, (diakses tanggal 16/9/2013) 
yang terekam di institusi KPK bahwa sejak tahun 2002 hingga Juli 2005 terdapat sekitar 331 laporan korupsi di Jawa Barat atau 5,7 \% dari total laporan korupsi di seluruh Indonesia ${ }^{13}$.

Kondisi terkini, per Agustus tahun 2013, sedikitnya terdapat14 109 kasus tindak pidana korupsi yang diproses oleh Polda Jawa Barat (akumulasi semua kasus di seluruh Polres di Jawa Barat). Dari 109 kasus tersebut, hanya 41 kasus yang P21. Pada tahun 2012, kasus korupsi yang sampai P21 dan ditangani di Pengadilan Tinggi Jawa Barat (Pengadilan Tipikor Bandung) sebanyak 43 kasus. Sementara itu, untuk tahun 2011 jumlah kasus yang sampai tahap P21 sebanyak 52 kasus. ${ }^{15}$

Tabel 1. Tabel Jumlah Kasus Korupsi yang Sampai P21 di Jawa Barat Tahun 2011, 2012, dan 2013

\begin{tabular}{ccc}
\hline No. & Tahun & Jumlah Kasus P21 \\
\hline 1. & 2011 & 53 \\
\hline 2. & 2012 & 43 \\
\hline 3. & Per Agustus 2013 & 41 \\
\hline
\end{tabular}

Sumber : Diolah oleh Penulis

Dari data di atas, tren kasus korupsi yang ditangani dari tahun ke tahun tidak terlalu jauh berbeda jika dilihat dari sisi jumlah. Bahkan cenderung mengalami penurunan. Namun jika dilihat dari potensi kerugian negara yang ditimbulkan akibat kasus korupsi di Jawa Barat cenderung mengalami peningkatan. Untuk tahun 2013, per Agustus kerugian negara yang ditimbulkan adalah Rp. 193.618.897.087,00. Jumlah ini cukup besar di bandingkan tahun 2011

13 www.antikorupsi.org., (diakses tanggal 19/9/2013)

14 Rekapitulasi data kasus korupsi selama tahun 2013 yang ditangani oleh jajaran POLDA Jawa Barat.

15 Laporan keadaan perkara tipikor tahun 2011 dan 2012 di Pengadilan Tinggi Jawa Barat. 
yang hanya Rp. 115.817.270.770,00.16 Hal ini menunjukkan bahwa potensi kerugian negara akibat korupsi di Jawa Barat dari tahun ke tahun cenderung mengalami peningkatan.

Ada beberapa faktor yang menyebabkan korupsi masih tumbuh subur di daerah. Dalam konteks Jawa Barat, faktor-faktor yang relevan yang menyebabkan mengapa pejabat publik banyak yang terlibat korupsi adalah :

\section{Pemaknaan yang Salah terhadap Arti Penyelenggara Pemerintahan Daerah adalah Pemerintah Daerah dan DPRD Menyebabkan Banyak Anggota DPRD yang Terjerat Korupsi}

Korupsi pejabat publik yang terjadi sebelum tahun 2014 di Jawa Barat banyak dipicu oleh pemaknaan yang salah terhadap UU Pemerintahan Daerah. Mengacu pada UU No. 32 Tahun 2004 tentang Pemerintahan Daerah, secara gamblang dinyatakan dalam pasal 3 ayat 1 huruf a, bahwa pemerintahan daerah adalah Pemerintah Daerah dan Dewan Perwakilan Rakyat Daerah (DPRD). Konsekuensinya, seperti dimaksud dalam pasal 19 ayat 2, penyelenggaraan pemerintahan daerah tidak hanya dijalankan oleh pemerintah daerah sebagai lembaga eksekutif, tetapi juga di jalankan oleh DPRD.

Jika dimaknai, hubungan antara pemerintah daerah/kepala daerah dan DPRD adalah setara dan bersifat kemitraan. Tidak ada yang lebih tinggi diantara keduanya. Menurut J. Kaloh, setidak-tidaknya ada tiga bentuk hubungan antara pemerintah daerah dan DPRD, yaitu (1) bentuk komunikasi dan tukar menukar informasi; (2) bentuk kerjasama atas beberapa subjek, program, masalah dan pengembangan regulasi; (3) klarifikasi atas berbagai permasalahan ${ }^{17}$.

Menurut Sadu Wasistiono, ada beberapa prinsip dasar dalam hubungan kerja antara kepala daerah dan DPRD. Sekurang-kurangnya ada enam aspek

\footnotetext{
16 Rekapitulasi data kasus korupsi selama tahun 2013 dan tahun 2011 yang ditangani oleh jajaran POLDA Jawa Barat.

${ }^{17}$ J Kaloh. 2007. Mencari Bentuk Otonomi Daerah Suatu Solusi Dalam Menjawab Kebutuhan Lokal dan Tantangan Global. PT Rineka Cipta: Jakarta.
} 
hubungan antara kepala daerah dan DPRD yang secara nyata terjadi dalam penyelenggaraan pemerintahan daerah, yaitu (1) penyusunan kebijakan daerah; (2) penyusunan APBD; (3) kebijakan strategis kepegawaian; (4) kebijakan strategis pengelolaan barang; (5) laporan keterangan pertanggungjawaban; dan (6) kebijakan pengawasan pelaksanaan peraturan perundang-undangan dan $\operatorname{anggaran}^{18}$.

Persoalannya adalah banyak anggota DPRD yang salah memaknai hubungannya dengan pemerintah daerah/kepala daerah. Anggota DPRD merasa punya kewenangan besar termaksud mencampuri segala urusan pemerintahan. Celakanya, kesalahan pemaknaan tersebut berdampak pada korupsi yang dilakukan secara bersama-sama. Andrinof A. Chaniago menyatakan bahwa anggota DPRD yang seharusnya berperan mengontrol tindakan eksekutif justru berkembang ke arah tindakan pemerasan uang negara secara bersama-sama. ${ }^{19}$

Apa yang terjadi di Jawa Timur seperti yang diungkap oleh Bambang Purwoko, bahwa di daerah muncul anekdot yang sekaligus sindiran terhadap kinerja legislatif dan eksekutif yakni "bagi dua atau bongkar". Maksudnya ketika legislatif menemukan indikasi penyimpangan yang dilakukan oleh eksekutif, maka mereka akan memaksa eksekutif untuk membagi rezeki itu atau mengancam eksekutif akan membongkar jika keinginan mereka tidak terpenuhi. ${ }^{20}$

Fenomena di Jawa Timur pada dasarnya tidak jauh berbeda dengan apa yang terjadi di Jawa Barat. Seperti yang terlihat pada tabel 4.1.2. tentang Pejabat Legislatif yang Terlibat Kasus Korupsi di Jawa Barat, jumlah anggota DPRD yang terlibat korupsi cukup besar. Dari data yang ada, kejadian yang sangat parah terjadi di Kota Bogor yakni terdapat sebanyak 34 anggota DPRD yang tersangkut kasus korupsi. Mereka terlibat kasus korupsi APBD dengan total kerugian negara sebesar 6,8 miliar. ${ }^{21}$

\footnotetext{
18 Sadu Wasistiono dan Yonatan Wiyoso, Meningkatkan Kinerja Dewan Perwakilan Rakyat Daerah (DPRD), Fokusmedia, Bandung, 2009.

19 Supra, catatan no. 9

20 Id

21 Harian Pikiran Rakyat, edisi 4 Januari 2010.
} 
Tumbuh suburnya perilaku koruptif di kalangan anggota DPRD di Jawa Barat disebabkan oleh beberapa hal diantaranya kompleksitas pola pengambilan kebijakan publik yang di dalamnya memberi peluang bagi manipulasi dan penyelewengan, termaksud misalnya dalam kasus masuknya agenda-agenda dari luar yang sering bertentangan dengan misi daerah.

Menurut Budi Budiman ${ }^{22}$ proses jual beli agenda dari luar atau proyek yang akan masuk dalam APBD terjadi jika proyek itu akan dilakukan di beberapa tempat. Misalnya ada beberapa daerah yang akan membangun stadion olah raga, sementara yang akan di danai oleh APBD hanya satu. Maka akan ada kompetisi antara daerah. Ketika terjadi kompetisi, maka anggota DPRD bisa bermain di wilayah ini dan dengan komitmen tertentu akan membantu menggolkan daerah mana yang akan mendapatkan proyek itu. Dalam konteks ini, suap bisa terjadi.

Kebutuhan partai politik untuk mendanai pemilu juga menjadi pemicu maraknya korupsi di lingkaran DPRD. Seperti yang diungkap oleh Budi Budiman, bahwa dalam sebulan saja mereka bisa menyetor hingga 10 juta. Gaji anggota DPRD untuk level provinsi bisa mencapai 30 juta. Belum lagi biaya-biaya ketika bertemu konstituen. Ada beberapa konstituen yang menyodorkan proposal bantuan dana. Tuntutan biaya politik tinggi seperti ini yang mendorong para anggota kreatif mencari sumber pendanaan lainnya. Persoalan kemudian muncul ketika usaha kreatif itu dilakukan melalui korupsi. Apalagi konsentrasi kekuasaan sangat kuat pada lembaga DPRD dalam ikut menentukan politik anggaran.

\section{Biaya Politik Tinggi di Jawa Barat}

Kompetisi dalam pilkada atau pun pemilu di daerah menuntut cost politik yang cukup besar. Untuk menjadi anggota DPRD sedikitnya memerlukan dana minimal kurang lebih Rp. 600 juta, bahkan bisa mencapai Rp. 6 miliar. Sementara untuk menjadi kepala daerah semisal gubernur, bupati atau walikota dana yang diperlukan lebih besar lagi. Sedikitnya minimal Rp. 40 miliar yang harus disiapkan jika ingin ikut kompetisi. Nilai dana tersebut biasanya digunakan untuk membayar

22 Wakil Ketua DPD PDIP Jawa Barat 
konsultan politik. Paling tidak tarif senilai Rp. 40 miliar, patokan dana dari LSI jika ingin menggunakan jasanya. Untuk bupati atau walikota minimal Rp. 20 miliar.

Fenomena cost politik yang besar mendorong banyak kepala daerah dan anggota DPRD yang terdorong untuk korupsi pasca dia menjabat. Hal ini banyak terjadi pada mereka yang tidak memiliki penyandang dana untuk kegiatan politiknya. Akibatnya salah satu cara pintas yang bisa dilakukan adalah dengan korupsi dana APBD. Hal ini juga diungkapkan oleh Budi Budiman, bahwa salah satu pemicu maraknya korupsi termasuk di Jawa Barat adalah politik biaya tinggi.

Biaya politik yang tinggi sebagai pemicu korupsi terjadi dalam kasus yang menimpa mantan Walikota Bekasi, Mochtar Muhammad dan mantan Bupati Subang, Eep Hidayat. Biaya politik yang dibutuhkan di dua daerah dalam konstelasi Pilkada minimal Rp. 40 Miliar. Dana tersebut tidak sebanding dengan penghasilan yang mereka terima selama masa jabatannya. Sebagai contoh penghasilan Walikota Bekasi perbulan adalah Rp.112.827.550,0023. Selama lima tahun menjabat, Walikota Bekasi hanya mampu mengumpulkan Rp 6,7 Miliar. Masih sangat jauh dibanding biaya politik yang dibutuhkan, sehingga tidak heran jika mantan Walikota Bekasi melakukan korupsi uang makan minum dan korupsi lainnya.

Kondisi yang sama juga terjadi pada mantan Bupati Subang. Dilihat dari penghasilan, sudah pasti bahwa penghasilan Walikota Bekasi lebih besar dari penghasilan Bupati Subang. Penghasilan Bupati Subang di bawah Rp. 6,7 Miliar. Sementara untuk maju sebagai calon Bupati cost nya sekitar 40 Miliar. Ketidakseimbangan ini memicu korupsi, sehingga tidak heran jika mantan Bupati Subang, Eep Hidayat terlibat korupsi Pajak Bumi dan Bangunan senilai Rp. 14 Miliar.

Penyebab lain biaya politik tinggi adalah pola rekrutmen pejabat politik oleh partai politik yang masih mengedepankan uang. Hal itu terjadi baik rekrutmen calon kepala daerah atau pun calon legislatif. Sistem yang berlaku

${ }^{23}$ APBD Kota Bekasi Tahun 2012 
selama ini adalah untuk mendapatkan rekomendasi pencalonan dari partai biasanya harus menyetor sejumlah uang dulu. Budiman Sujatmiko24, mengungkapkan bahwa rekrutmen politik yang salah dan tidak transparan cenderung mengakibatkan semakin suburnya tindak pidana korupsi, seperti dalam pemilihan kepala daerah atau anggota legislatif. Misalnya untuk mendapatkan rekomendasi, dia membayar berapa miliar entah itu untuk menjadi kepala daerah maupun untuk menjadi anggota legislatif. ${ }^{25}$

Karena pola rekrutmen yang salah, maka melahirkan pejabat politik yang salah. Resiko terbesar dari pola rekrutmen seperti ini adalah melahirkan pejabat politik korup. Mereka cenderung berfikir bagaimana mengembalikan modal besar yang suda terbuang. Akibatnya muncul upaya-upaya kreatif untuk menggerogoti dana APBD. Bukannya konsentrasi mengurus rakyat, yang ada adalah sibuk memikirkan proyek mana yang bisa disunat. Tidak hanya sekedar untuk mengembalikan modal, tetapi untuk investasi politik jangka panjang agar bisa maju kembali untuk periode selanjutnya.

\section{Banyaknya Celah dalam Regulasi yang Bisa Dipakai untuk Menyimpangkan Anggaran}

Celah regulasi yang biasa dimanfaatkan untuk korupsi adalah adanya peraturan perundang-undangan tentang pelaksanaan APBD yang membenarkan penunjukan langsung tanpa tender. Hal ini memberi ruang pada korupsi dalam implementasi program. Seperti yang diungkap oleh Agus ${ }^{26}$ bahwa di Jawa Barat, peluang korupsi banyak terjadi di tataran implementasi program. Menurutnya dalam tahap perencanaan APBD jarang terjadi korupsi.

Penunjukan langsung proyek berkaitan dengan pengadaan barang dan jasa. Sektor ini paling banyak menjadi lahan korupsi di daerah termaksud di Jawa Barat. Hasil penelitian litbang Kompas menyebutkan bahwa dalam rentang 2004-

\footnotetext{
${ }^{24}$ Anggota DPR dari PDIP

25 Kompas, edisi 6 September 2013

${ }^{26}$ Anggota Tim Anggaran Pemerintah Jawa Barat
} 
2011, modus korupsi paling tinggi adalah dalam pengadaan barang dan jasa. Sedikitnya terdapat 96 modus, sedangkan peringkat selanjutnya adalah penyuapan 82 modus, penyalagunaan anggaran 35 modus, pungutan 12 modus, dan perizinan 10 modus. ${ }^{27}$

Sebagian besar dana APBD digunakan untuk pelayanan publik, sehingga tidak heran banyak anggaran yang tersedot melalui pengadaan barang dan jasa. Pelayanan publik salah satunya nyata dalam pengadaan barang dan jasa. Di Jawa Barat sendiri, korupsi banyak terjadi dalam pola ini. Spesifikasi yang sering muncul dalam modus ini adalah mark up dana proyek. Kasus yang cukup menghebohkan adalah yang menimpa Dany Setiawan, mantan gubernur jawa barat dalam kasus pengadaan mobil pemadam kebakaran di lingkungan pemerintah Jawa Barat.

Kasus lain adalah yang menimpa Suryana yang pernah menjadi anggota DPRD Kota Cirebon. Karena ada mekanisme penunjukkan langsung dengan aturan yang tidak ketat, Suryana terjerat kasus penyelewengan dana belanja barang dan jasa senilai Rp. 4,9 Miliar dalam APBD Kota Cirebon Tahun 2004.

\section{Solusi Agar Penyelesaian Kasus Korupsi Terutama yang Melibatkan Pejabat Publik Bisa Lebih Efektif}

Untuk mengurai solusi berdasarkan temuan-temuan terkait dengan korupsi dan kinerja lembaga penegak hukum dalam pemberantasan korupsi di Jawa barat, maka secara umum beberapa cara untuk memaksimalkan agar peran lembaga penegak hukum bisa lebih efektif dalam memberantas korupsi, yaitu:

\section{Diperlukan Regulasi terkait Sistem Anggaran Penyelidikan dan Penyidikan dengan Model At Cost}

Tidak bisa dipungkiri bahwa penyelesaian kasus korupsi membutuhkan kerja ekstra dari lembaga penegak hukum dalam pengumpulan bukti-bukti. Agar

${ }^{27}$ Kompas, 18 April 2012 
para penyidik baik di kepolisian dan kejaksaan bisa lebih maksimal maka mestinya mereka diberi kebebasan penuh termaksud dukungan anggaran penuh. Dengan dukungan anggaran yang memadai, maka ruang gerak para penyidik bisa lebih luas. Para penyidik bisa melakukan berbagai cara untuk mengumpulkan bukti-bukti agar sebuah kasus bisa terungkap.

Fakta yang terjadi terkadang penyidik malas-malasan mengumpulkan bukti karena anggaran penyidikannya minim. Hal ini terjadi karena jatah penyidikan sudah dibatasi berdasarkan jumlah kasus. Akibatnya jika jumlah kasus yang ditangani melebihi dari jatah, maka anggarannya harus dicari terlebih dahulu kira-kira akan diambilkan dari sumber apa. Untuk mengatasi hal ini, maka sistem anggaran et cost menjadi penting. Para penyidik bisa melakukan aktivitas pencarian bukti-bukti dengan anggaran berapapun dan diakhir bisa di reimburse. Dengan demikian penyidik perkara korupsi bisa lebih leluasa tanpa dibatasi karena ketiadaan anggaran.

\section{Perbaikan Regulasi tentang Undang-undang Kejaksaan untuk Mewujudkan Independensi Kejaksaan terutama dalam Pemberantasan Korupsi termaksud Korupsi di Daerah}

Aturan tentang kejaksaan bisa ditemukan dalam Undang-undang Nomor 16 Tahun 2004. Dalam regulasi tersebut, sesungguhnya kejaksaan kurang memiliki independensi karena disatu sisi kejaksaan menjalankan fungsi yudikatif, namun disisi lain Jaksa tertinggi dalam hal ini Jaksa Agung diangkat oleh presiden tanpa melalui mekanisme di DPR. Akibatnya Jaksa Agung menjadi bawahan presiden dan konsekuensinya harus tunduk dan patuh pada presiden.

Masalah yang muncul dengan situasi seperti ini adalah jika ada kepala daerah atau pejabat publik lain di daerah yang terkena kasus korupsi maka intervensi politik bisa saja terjadi. Ruang untuk itu sangat mungkin dilakukan karena doktrin di kejaksaan bahwa jaksa itu satu. Mekanisme penyidikan kasus pun melalui izin hingga ke level paling atas. Proses penyelidikan satu kasus 
korupsi bisa saja dihentikan jika kepala daerah atau pejabat publik lain yang terindikasi korupsi memiliki backing politik dari atas atau misalnya dari partai politik yang masuk dalam lingkaran kekuasaan.

Dalam kaitan dengan hal ini, Romli Atmasasmita mengemukakan bahwa kemandirian kejaksaan tidak terkepas dari fungsi, wewenang, dan tugas kejaksaan di satu sisi dan landasan hukum organisasi kejaksaan di sisi lain sebagai bagian dari eksekutif. Peran ganda ini sangat resisten terhadap upaya mencapai keadilan. Untuk mengatasi permasalahan ini sangat tergantung pada sikap dan tekad politik pemerintah. Oleh karena itu perlu dilakukan evaluasi terhadap aturan tentang organisasi kejaksaan.

\section{Membentuk Unit Khusus Tipikor yang Terpisah dari Direktorat Reskrim di Lembaga Kepolisian}

Selama ini tipikor berada di bawah Direktorat Reserse dan Kriminal. Tipikor menjadi salah satu unit khusus yang mekanisme kerjanya masih dikoordinasikan oleh Kepala Bagian Reserse dan Kriminal. Disetiap tingkatan kepolisian kondisinya seperti itu baik di Mabes Polri, Polda maupun Polres. Posisi tipikor sebagai unit dirasa kurang maksimal dalam penanganan kasus korupsi. Kendala panjangnya koordinasi dan berjenjangnya instruksi pada saat pelaksanaan tugas menjadi kendala efektivitas kerjanya. Oleh karena itu muncul wacana menjadikan unit tipikor sebagai direktorat khusus yang langsung berada di bawah Kapolri, Kapolda dan atau Kapolres.

Wacana tersebut penting untuk ditindaklanjuti. Di Polda Jawa Barat sendiri wacana tersebut begitu kuat untuk dilaksanakan. Pertimbangannya adalah pengusutan kasus korupsi akan lebih maksimal karena tentunya dengan berdiri sebagai satu direktorat sendiri, maka personilnya akan lebih diperhatikan dari sisi jumlah dan tentunya kualitas orang-oramngnya pun bisa jadi prioritas. 


\section{Pengadilan Tipikor Di Tingkat Provinsi di Perbanyak Misalnya terdapat Dalam Beberapa Area dan Tidak Terpusat di Satu Tempat} Saja

Seperti diungkap oleh Sri Kuncoro ${ }^{28}$, bahwa banyak jaksa yang menangani kasus korupsi di wilayah hukum Jawa Barat mengalami kendala teknis dalam proses peradilan. Kendala teknis tersebut banyak dialami oleh jaksa-jaksa yang berada jauh dari Kota Bandung. Pengadilan Tipikor di Provinsi Jawa Barat hanya ada satu dan berlokasi di Kota Bandung. Akibatnya semua kasus korupsi menumpuk di satu pengadilan tipikor saja.

Dampak yang paling langsung dirasakan oleh Jaksa yang cukup jauh dari Kota Bandung yang menangani perkara korupsi adalah efektivitas waktu dan tenaga. Dari sisi waktu cukup memakan waktu karena perjalanan yang cukup panjang ketika proses perkara. Dari sisi tenaga cukup menguras tenaga dan berdampak pada konsentrasi jaksa saat berperkara di pengadilan.

Dampak lain adalah dirasakan oleh para hakim. Jumlah hakim tipikor di Kota Bandung hanya 14 orang. Jumlah ini dirasa kurang jika dibandingkan dengan kasus yang masuk. Hal ini berdampak pada kualitas putusan. Para hakim bekerja di bawah tekanan waktu. Jumlah kasus yang banyak sangat mempengaruhi kondisi psikologis para hakim. Di satu sisi mereka dituntut untuk memperhatikan kualitas putusan namun di sisi lain mereka punya target berapa jumlah kasus yang harus diselesaikan dalam periode tertentu. Oleh karena itu agar penyelesaian kasus korupsi bisa lebih maksimal perlu dibuat beberapa peradilan tipikor dalam satu provinsi.

\section{Memaksimalkan Peran Lembaga Penegak Hukum dengan cara perbaikan legal culture}

Solusi yang bisa dilakukan dengan prespektif ini adalah perubahan cara berfikir para aparat penegak hukum dalam memandang profesi mereka. Hal ini

\footnotetext{
${ }^{28}$ Koordinator Jaksa Tipikor Kejaksaan Tinggi Jawa Barat
} 
akan berpengaruh pada kinerja mereka dalam pemberantasan korupsi. Pola pikir yang harus dibangun adalah bahwa profesi penegak hukum merupakan profesi mulia dalam menegakkan keadilan di masyarakat. Profesi penegak hukum bukan profesi untuk memperkaya diri. Paradigma yang harus dibangun adalah menjadi aparat penegak hukum sebagai pengabdian.

Pola pikir yang benar dari aparat penegak hukum dapat menghindari suap sehingga mereka bisa bekerja secara profesional. Masyarakat juga punya peranan dalam hal ini, dimana kesadaran masyarakat harus terbangun untuk tidak mengembangkan budaya suap. Masyarakat justru dituntut sebagai kontrol atas perilaku aparat penegak hukum yang melenceng, dan bukan sebagai penggoda jika berperkara dengan mengiming-imingi uang kepada aparat supaya kasusnya dimenangkan.

\section{Penutup}

Kesimpulan dalam penelitian ini adalah:

1. Korupsi yang terjadi di Jawa Barat mayoritas dalam bentuk Kerugian Keuangan Negara dan modus korupsinya meliputi:

a) Modus korupsi di level Kepala Daerah meliputi mark-up proyek, suap, korupsi dana APBD, dan korupsi dana bansos;

b) Modus korupsi di level anggota DPRD meliputi korupsi dana bansos, korupsi dana APBD, dan korupsi dana bencana alam;

c) Modus korupsi di level birokrasi meliputi suap, mark-up, dan pembukuan yang tidak benar.

2. Kasus korupsi di Jawa Barat yang disebabkan oleh beberapa faktor diantaranya pemaknaan yang salah terhadap makna pemerintahan daerah, biaya politik tinggi, dan pemanfaatan celah dalam regulasi.

3. Untuk mendorong agar kinerja lembaga penegak hukum di Jawa Barat bisa lebih efektif dalam penanganan kasus korupsi maka dapat dilakukan perbaikan 
dalam tiga sektor, yaitu sektor regulasi, sektor struktur kelembagaan, dan sektor budaya hukum aparat.

Berdasarkan kesimpulan penelitian ini, maka terdapat beberapa saran, yaitu:

1. Departemen Keuangan harus menerapan sistem anggaran at cost dalam proses penyelidikan dan penyidikan di lembaga kepolisian dan kejaksaan;

2. DPR melakukan revisi Undang-undang Nomor 16 Tahun 2004 tentang kejaksaan yakni lembaga kejaksaan posisinya harus lebih kuat sebagai lembaga yudikatif bukan lembaga eksekutif;

3. Kepolisian membuat Regulasi agar Jika terjadi Kasus Korupsi yang Melibatkan Kepala Daerah atau Pejabat Tinggi lain Di Daerah maka Penyidikan Kasus Tersebut Ditangani oleh Tingkatan Kepolisian yang Lebih Tinggi;

4. Kepolisian membentuk Unit Khusus Tipikor yang Terpisah dari Direktorat Reskrim;

5. Mahkamah Agung memperbanyak Pengadilan Tipikor Di Tingkat Provinsi minimal dua.

\section{Daftar Pustaka}

Buku-Buku:

Friedman, Lawrenca M. 1975. The legal system: a social science perspective. New York: Russel Sage Foundation

Haboddin, Muhtar dan Rahman, Fathur. 2013. Gurita Korupsi Pemerintah Daerah. Yogyakarta: Kaukaba Dipantara

Kadish, Sanford H. 1983. Encyclopedia of Crime and Justice. The Free Press, 1983

Wattimena, Reza A.A. 2012. Filsafat Anti Korupsi. Yogyakarta: Kanisius

Kumpulan Makalah:

Akbar, Patrialis. 2010. Peran Kementerian Hukum dan Hak Asasi Manusia dalam Menciptakan Supremasi Hukum. Jurnal Sekretariat Negara

Prasetianingsih, Rahayu. Negara hukum dan penegakan hukum dalam "Negara Hukum yang Berkeadilan" Kumpulan Tulisan dalam Rangka Purnabakti Prof. Dr. Bagir Manan, S.H., M.CL., PSKN FH UNPAD, Bandung 
Sidharta, B. Arief. 2011. Asas hukum, kaidah hukum, sistem hukum dan penemuan hukum, dalam "Negara Hukum yang Berkeadilan" Kumpulan Tulisan dalam Rangka Purnabakti Prof. Dr. Bagir Manan, S.H., M.CL., PSKN FH UNPAD

Undang-Undang:

Undang-Undang No. 8 Tahun 1981 Tentang Kitab Undang-Undang Hukum Acara Pidana

Undang-Undang Nomor 20 Tahun 2001 Tentang Perubahan Atas Undang-Undang Nomor 31 Tahun 2999 Tentang Pemberantasan Tindak Pidana Korupsi

Undang-Undang Nomor 32 Tahun 2004 Tentang Pemerintahan Daerah

Undang-undang Nomor 7 Tahun 2006 tentang Pengesahan Konvensi PBB Anti Korupsi, 2003

Undang-Undang No 46 Tahun 2009 tentang Pengadilan Tindak Pidana Korupsi

Media Cetak dan Online:

www.antikorupsi.org., diakses tanggal 19 September 2013 